\title{
Change in Properties of Polycarbosilane-Derived SiC Fibers at High Temperatures
}

\author{
Toshio SHIMOO, Ichiro TSUKADA*, Masaki NARISAWA, Tadao SEGUCHI** and Kiyohito OKAMURA \\ Department of Metallurgy and Materials Science, College of Engineering, Osaka Prefecture University, 1-1, Gakuen-cho, Sakai-shi 593 \\ *Graduate Student, Osaka Prefecture University, 1-1, Gakuen-cho, Sakai-shi 593 \\ **Takasaki Radiation Chemistry Research Establishment, Japan Atomic Energy Research Institute, \\ 1233, Watanuki-machi, Takasaki-shi 370-12
}

\author{
ポリカルボシランを前駆体とする SiC 系繊維の高温における特性変化 \\ 下尾聰夫・塚田一郎*・成澤雅紀・瀬口忠男**・岡村清人 \\ 大阪府立大学工学部材料工学科, 593 堺市学園町 1-1 \\ *大阪府立大学大学院生, 593 堺市学園町 1-1 \\ ***本原子力研究所高崎研究所, 370-12 高崎市綿貫町 1233
}

\begin{abstract}
Using two types of polycarbosilane-derived SiC fibers, namely, Hi-Nicalon (1.8 mass\% oxygen) and Nicalon NL400 (13 mass\% oxygen) changes in their properties and the mechanism of deterioration were investigated at $1873 \mathrm{~K}$. A short period pyrolysis changed rapidly the properties such as gas generation, tensile strength, crystallite size of $\beta$-SiC and specific resistivity. The pyrolysis and the resultant crystal growth proceeded from the surface to the core of Nicalon. The fiber strength was proportional to the reciprocal square root of crystallite size. The formation of surface flaw, as well as coarsening of crystals, was an important factor controlling the fiber strength. Nicalon, which was porous after pyrolysis, deteriorated severely. On the other hand, Hi-Nicalon retained high levels of strength because of slow crystal growth and suppressed gas liberation. [Received December 24, 1996; Accepted May 9, 1997]
[
\end{abstract}

Key-words : Polycarbosilane-derived SiC fiber, Pyrolysis, Tensile strength, Crystal growth, Gas generation, Mechanism of deterioration

\section{Introduction}

Polycarbosilane-derived SiC fibers are potentially useful as reinforcing fibers for ceramic matrix composites. SiC fiber prepared by oxidation curing method (Nicalon by Nippon Carbon Co.) shows severe degradation in tensile strength at $1573 \mathrm{~K}$ and higher. This is due to the abundant presence of unstable silicon oxycarbide phase, which decomposes to $\beta$ - $\mathrm{SiC}$ crystal to generate $\mathrm{SiO}$ and $\mathrm{CO}$ gases. Thus, marked degradation of strength was caused by the coarsening of $\beta$-SiC crystals and the damaging effect of the gas generation to the fiber structure. The reduction in oxygen content, therefore, is effective in improving the thermal stability of SiC fiber. Recently, the effective fabrication method of low-oxygen SiC fiber (Hi-Nicalon by Nippon Carbon $\mathrm{C}_{0}$.) have been developed by using electron-beam irradiation curing method. ${ }^{1), 2)}$ As might be expected, the high level of strength was retained at higher temperature than was observed in Nicalon. For example, Hi-Nicalon heattreated at $1973 \mathrm{~K}$ retained one third of the original strength. On the other hand, the heat treatment of Nicalon led to an unmeasurable tensile strength even at $1873 \mathrm{~K}$.

In both of the fibers, a short time of heating at high temperature caused abrupt deterioration of strength. ${ }^{3)-5}$ ) Initially in high-temperature decomposition (pyrolysis), the structural changes of $\mathrm{SiC}$ fibers seem to occur rapidly. The objective of this study is to reveal the initial change in the properties of the SiC fibers and to explain the mechanism by which the fiber strength deteriorates abruptly at the earliest stage of pyrolysis. Furthermore, the degradation mechanism of Hi-Nicalon was compared with Nicalon.

\section{Experimental procedure}

Two types of polycarbosilane-derived SiC fibers employed in this study are: Hi-Nicalon and Nicalon NL400. HiNicalon was fabricated in laboratory by firing the electron beam cured polycarbosilane fiber at $1273 \mathrm{~K}$. Commercially available Nicalon NL400, which was fabricated by oxidation curing method, also was fired at $1273 \mathrm{~K}$. Hi-Nicalon and Nicalon have molar composition of $\mathrm{SiC}_{1.40} \mathrm{O}_{0.05}$ and $\mathrm{SiC}_{1.21} \mathrm{O}_{0.40}$, respectively. The large differences in oxygen content is prominent between both fibers: 1.8 mass $\% \mathrm{O}$ for $\mathrm{Hi}-\mathrm{Nicalon}$ and 13 mass $\% \mathrm{O}$ for Nicalon.

High-temperature heat treatment of fibers was conducted with a $\mathrm{SiC}$ resistance furnace equipped with a thermobalance. One gram fiber of $3 \mathrm{~cm}$ length was charged in a graphite crucible and then was heated in the hot zone of the furnace held at $1873 \mathrm{~K}$. The heating times were 1, 3, 30 and $60 \mathrm{~min}$. Argon gas was flowed from the bottom of the furnace at $2.5 \times 10^{-5} \mathrm{~m}^{3} \cdot \mathrm{s}^{-1}$. The mass change was recorded automatically during each run. Upon completion of TG measurement, the fibers were cooled rapidly by raising the crucible to the low temperature zone of the furnace.

The fibers were examined with the X-ray diffractometer (XRD; Rigaku International Co., RINT 11000) and by the scanning electron microscope (SEM; Hitachi Ltd, Type S5400). Using the two-terminal method, the specific resistivity was determined by applying direct current. Both ends of a monofilament were attached with electron conductive resin (Fujikura Kasei Co., Dotite) to the copper electrode plates which were $0.8 \mathrm{~mm}$ apart in distance. Furthermore, the tensile strength of a monofilament with $10 \mathrm{~mm}$ gauge length was determined with a universal tensile testing instrument (Orientec Co., Type TENSILON UTM-II20) and a load cell of $100 \mathrm{~g}$ at a crosshead speed of $2 \mathrm{~mm}$. $\min ^{-1}$.

\section{Results}

Figure 1 shows TG curves for Hi-Nicalon and Nicalon NL400 heated at $1873 \mathrm{~K} .100 \cdot \Delta W / W_{0}$ is the ratio of the mass loss determined by TG to the initial mass of fiber. The observed mass loss was due to the generation of $\mathrm{SiO}$ and $\mathrm{CO}$ gases. ${ }^{6), 7)}$ Nicalon liberated violently more gases than $\mathrm{Hi}$ - 


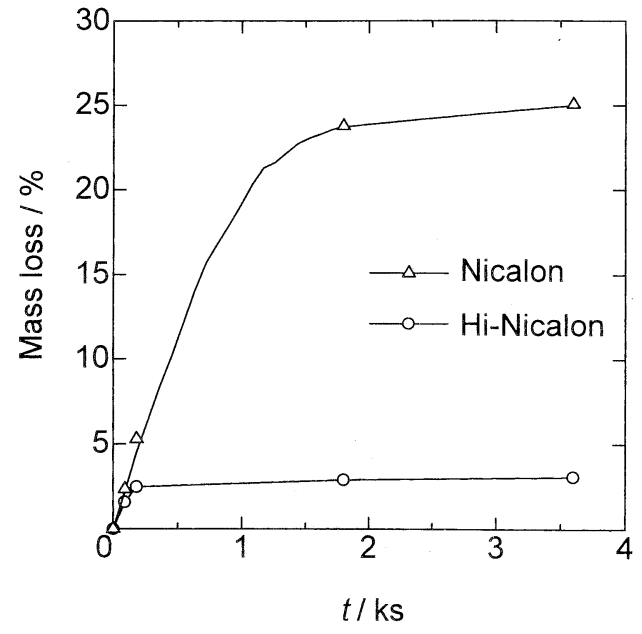

Fig. 1. TG curves for fibers heated at $1873 \mathrm{~K}$.

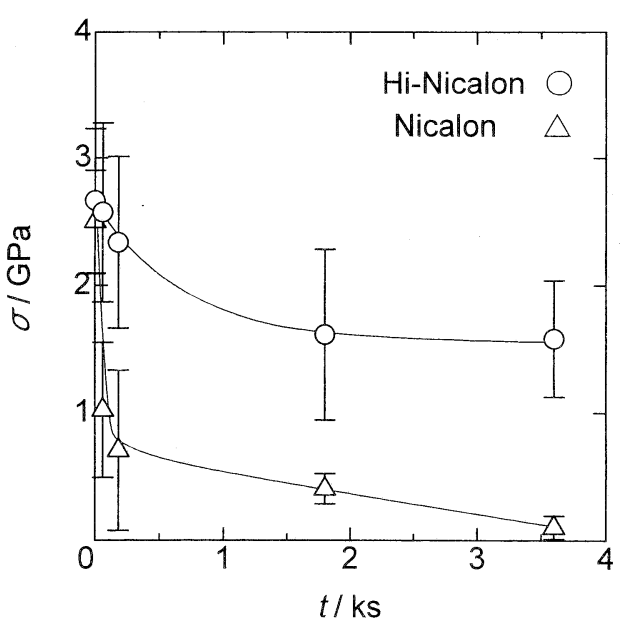

Fig. 2. Tensile strength of fibers heated at $1873 \mathrm{~K}$ as function of heating time.

Nicalon. After $3.6 \mathrm{ks}$, the mass loss for Nicalon was about ten times larger than Hi-Nicalon. The gas generation from Hi-Nicalon was practically completed in a short period of $180 \mathrm{~s}(3 \mathrm{~min})$.

The relationship between the tensile strength of fibers and heating time is shown in Fig. 2. Both as-received fibers had nearly identical strength: $2.65 \mathrm{GPa}$ for Hi-Nicalon and $2.49 \mathrm{GPa}$ for Nicalon. The tensile strength of Nicalon was drastically degraded by a brief period of heating. The strength of Nicalon heated for $0.18 \mathrm{ks}$ retained merely $28 \%$ of original strength. Then, it was lost nearly completely after $3.6 \mathrm{ks}$. On the other hand, the degradation of Hi-Nicalon was less severe and $60 \%$ of original strength was retained even after $3.6 \mathrm{ks}$.

Figures 3 and 4 show X-ray diffraction patterns of $\mathrm{Hi}$ Nicalon and Nicalon heated at $1873 \mathrm{~K}$, respectively. In the as-received state, Nicalon was more amorphous than $\mathrm{Hi}$ Nicalon. After heat treatment, Hi-Nicalon crystallized more sharply into $\beta$ - $\mathrm{SiC}$ compared to Nicalon. In addition, for $\mathrm{Hi}-$ Nicalon heat-treated, the weak peak, which originated from carbon, was observed at diffraction angle $(2 \theta)$ of about $26^{\circ}$. Thus, Hi-Nicalon seems to decompose into the mixture of $\beta$-SiC and free carbon.

The apparent crystal size of $\beta$-SiC, $D_{111}$, was calculated from the half-value width of (111) peak of $\beta$-SiC, using a Scherrer's formula. The relationship between the crystal

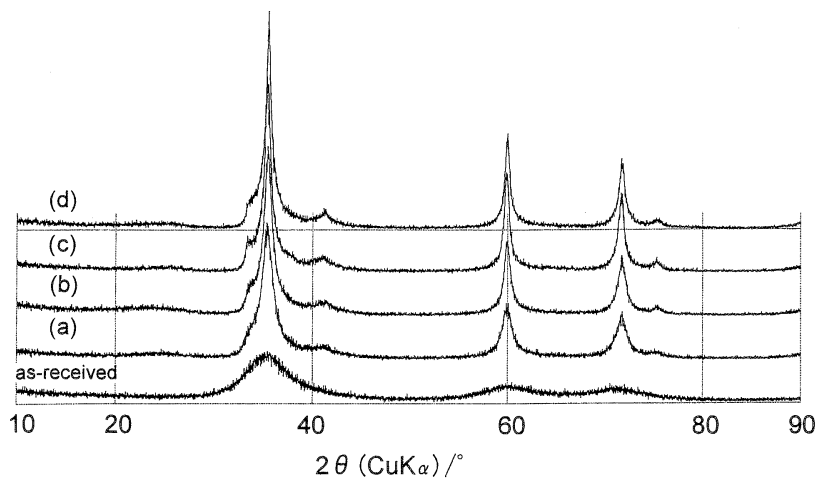

Fig. 3. X-ray diffraction patterns of Hi-Nicalon heated at $1873 \mathrm{~K}$ for $1.5 \mathrm{~min}(\mathrm{a}), 3 \mathrm{~min}$ (b), $30 \mathrm{~min}$ (c) and $60 \mathrm{~min}$ (d).

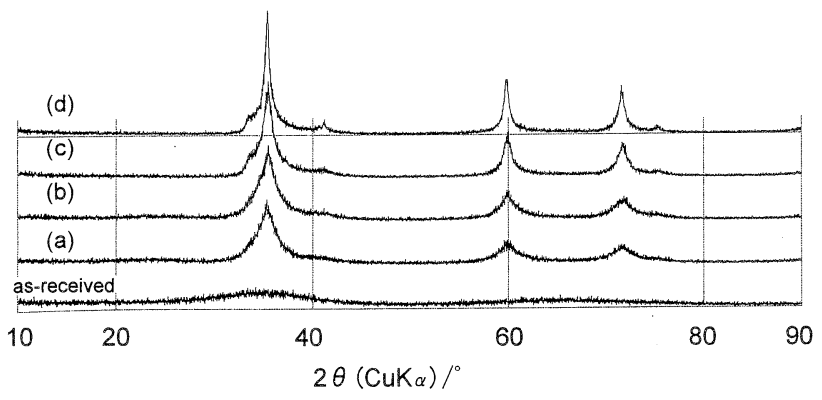

Fig. 4. X-ray diffraction patterns of Nicalon heated at $1873 \mathrm{~K}$ for $1.5 \mathrm{~min}$ (a), $3 \mathrm{~min}(\mathrm{~b}), 30 \mathrm{~min}$ (c) and $60 \mathrm{~min}(\mathrm{~d})$

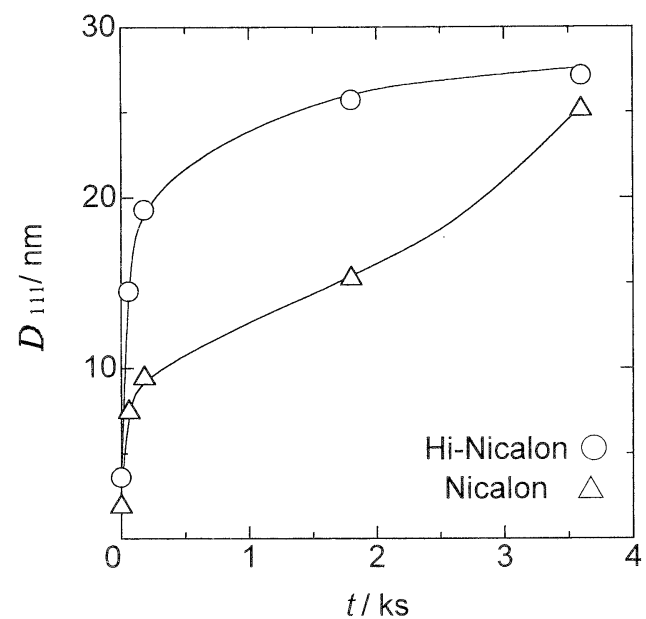

Fig. 5. Apparent crystal size of $\beta$-SiC in fibers heated at $1873 \mathrm{~K}$ as function of heating time.

size and heating time is shown in Fig. 5. $\beta$-SiC crystals grow rapidly within a brief period, $180 \mathrm{~s}$. This tendency was enhanced particularly in Hi-Nicalon. The subsequent heating at $1873 \mathrm{~K}$ hardly coarsens $\beta$-SiC crystals in Hi-Nicalon, while still continued to coarsen $\beta$-SiC crystals in Nicalon. Finally, the crystal size of Nicalon approached that of Hi-Nicalon after $3.6 \mathrm{ks}$.

The specific resistivity of $\mathrm{SiC}$ fibers is the structure-sensitive property. Figure 6 shows the specific resistivity of fibers heated at $1873 \mathrm{~K}$. In the as-received state, Hi-Nicalon showed about 100 times smaller resistivity than Nicalon. During heating for $180 \mathrm{~s}$, the resistivity of both fibers was rapidly lowered by four orders of magnitude. It might be 


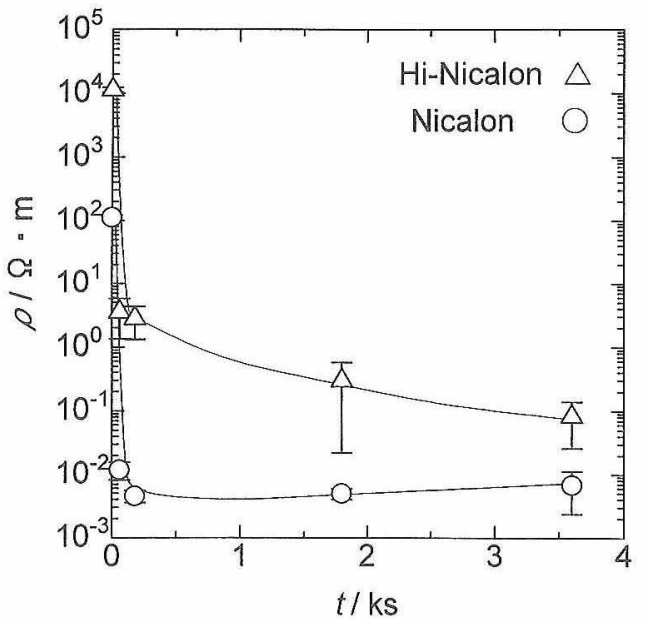

Fig. 6. Specific resistivity of fibers heated at $1873 \mathrm{~K}$ as function of heating time.

noted that the resistivity of Hi-Nicalon was no longer decreased by prolonging the heating time. This result implied the completion of the high-temperature decomposition, i.e., the perfect transformation into the mixture of free carbon and $\beta$-SiC. ${ }^{3), 4)}$ For Nicalon, however, the gradual reduction in the resistivity was observed because $\mathrm{SiO}$ and $\mathrm{CO}$ gases still generated beyond $180 \mathrm{~s}$. In addition, the corresponding changes in tensile strength and $\beta$-SiC crystal size also were observed. The presence of free carbon lowered the resistivity of $\mathrm{Hi}-\mathrm{Nicalon}$ by one to three orders of magnitude compared to Nicalon which decomposed to only $\beta$-SiC. ${ }^{6)-8)}$

Figures 7 and 8 show the morphologies of fibers heated at $1873 \mathrm{~K}$ for different periods of time. The grain structures of fiber surface were markedly coarsened with increasing heating times. Then, huge grains, which were found at fiber surface, also might be regarded as $\beta$-SiC crystals. The outward growth of grains suggested that they were produced

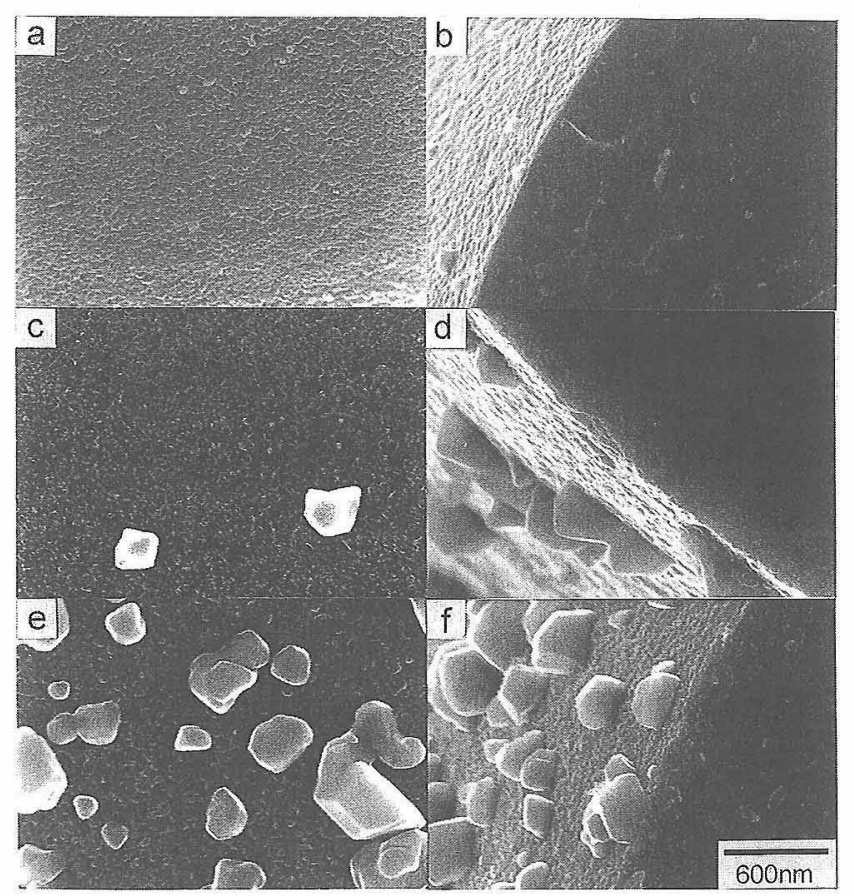

Fig. 7. SEM photographs of Hi-Nicalon heated at $1873 \mathrm{~K}$ for 3 $\min (a, b), 30 \min (c, d)$ and $60 \min (e, f)$.

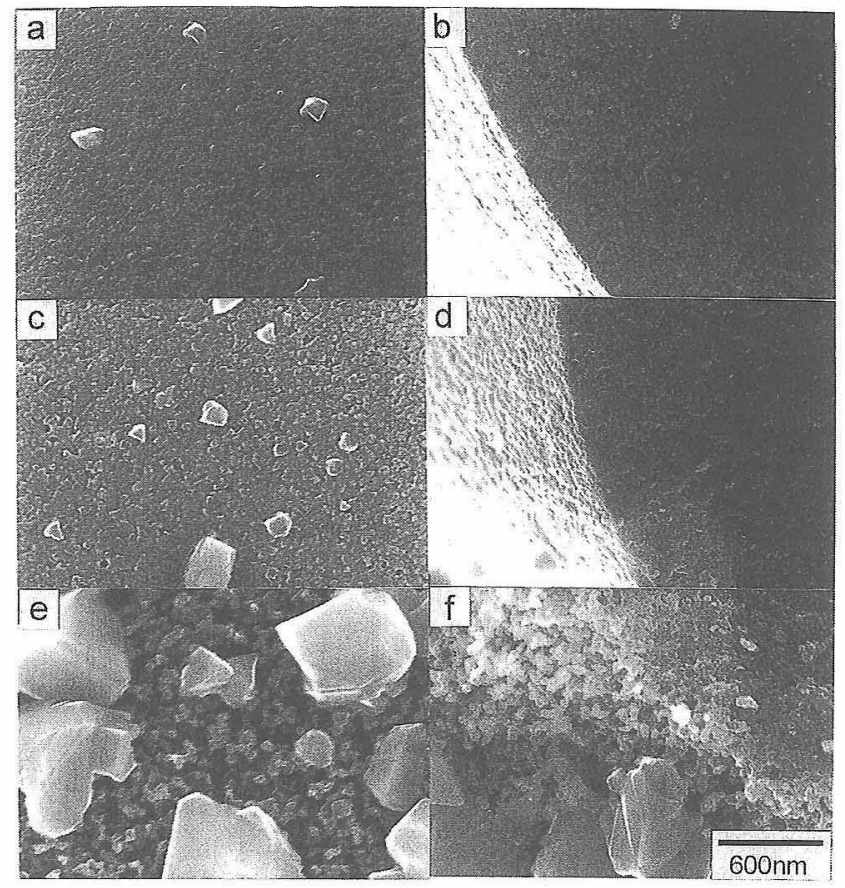

Fig. 8. SEM photographs of Nicalon heated at $1873 \mathrm{~K}$ for $3 \mathrm{~min}$ $(\mathrm{a}, \mathrm{b}), 30 \mathrm{~min}(\mathrm{c}, \mathrm{d})$ and $60 \mathrm{~min}(\mathrm{e}, \mathrm{f})$.

by gas-phase reaction. Hi-Nicalon showed a dense and poreless structure from surface to core, though $\beta$-SiC crystals were coarsened by a brief time of heating (Fig. 7). On the other hand, the formation of many micro-pores characterized the surface of Nicalon (Fig. 8). The cross section of Nicalon exhibited that $\beta$-SiC crystals coarsened inwardly from the surface to the core. While the core of Nicalon heated for 3 min showed a fine-grained structure, its surface had a coarsened structure (Fig. 8(b)). After $30 \mathrm{~min}$, the coarsened structure was observed over the whole cross section (Fig. 8(d)). A long period of heating resulted in the increase in porosity of fiber as well as crystal size of $\beta$-SiC. Numerous micro-pores were observed at the fiber surface even after a brief heating period of $3 \mathrm{~min}$, and then increased in size during long period of heating. The micropores, which were responsible for severe degradation of tensile strength, were considered to be caused by the evolution of pyrolytic gases.

\section{Discussion}

The changes in TG (Fig. 1), strength (Fig. 2), crystal size (Fig. 5) and resistivity (Fig. 6) of both fibers were significantly sharp within 3 min $(0.18 \mathrm{ks})$. The properties of Hi-Nicalon were hardly changed beyond $30 \mathrm{~min}(1.8 \mathrm{ks})$, indicating that the pyrolysis was completed. On the other hand, the properties of Nicalon continued to be changed gradually even after heating one hour $(3.6 \mathrm{ks})$. Such results are contributable to the difference in oxygen content of fibers. Nicalon and Hi-Nicalon are amorphous SiC fibers which contain oxygen as well as excess carbon. The microstructure is the nano-scale mixture of micro-crystalline $\beta$ $\mathrm{SiC}$, aromatic carbon and amorphous silicon oxycarbide, $\mathrm{SiC}_{x} \mathrm{O}_{y}{ }^{9)}$-11) The aromatic carbon is considered to form a continuous network of carbon cages around $\mathrm{SiC}$ crystals. On heating at higher temperatures, amorphous $\mathrm{SiC}_{x} \mathrm{O}_{y}$ phases, which are thermodynamically unstable, tend to crystallize into $\beta$-SiC. The crystal growth involves the diffusion of silicon and carbon atoms from $\mathrm{SiC}_{x} \mathrm{O}_{y}$ phase to microcrystalline $\beta$-SiC. Such a crystallization increases the oxygen content of undecomposed $\mathrm{SiC}_{x} \mathrm{O}_{y}$ phase, until oxygen is 
liberated as both $\mathrm{SiO}$ and $\mathrm{CO}$ gases. Thus, the pyrolysis of $\mathrm{SiC}_{x} \mathrm{O}_{y}$ results in the following reaction:

$$
\mathrm{SiC}_{x} \mathrm{O}_{y} \rightarrow \mathrm{SiC}(\mathrm{s})+\mathrm{SiO}(\mathrm{g})+\mathrm{CO}(\mathrm{g})
$$

The pyrolysis of Hi-Nicalon with the molar composition of $\mathrm{SiC}_{1.40} \mathrm{O}_{0.05}$ retains a large excess of carbon. The composition of pyrolyzed fiber is $\mathrm{SiC}_{1.35}$ even if all of oxygen is liberated as $\mathrm{CO}$ gas. Hi-Nicalon, therefore, will crystallize into the mixture of $\beta$-SiC and free carbon:

$$
\mathrm{SiC}_{1.40} \mathrm{O}_{0.05} \rightarrow \mathrm{SiC}(\mathrm{s})+\mathrm{C}(\mathrm{s})+\mathrm{SiO}(\mathrm{g})+\mathrm{CO}(\mathrm{g})
$$

Free carbon was detected by $\mathrm{X}$-ray diffraction, as shown in Fig. 3. Then, the lower resistivity of Hi-Nicalon is contributable to the presence of free carbon (Fig. 6). On the other hand, on heating Nicalon to high temperatures, all of aromatic carbon may be oxidized by large amounts of $\mathrm{SiC}_{x} \mathrm{O}_{y}$ phase.

$$
\mathrm{C}(\mathrm{s})+\mathrm{SiC}_{x} \mathrm{O}_{y} \rightarrow \mathrm{SiC}(\mathrm{s})+\mathrm{SiO}(\mathrm{g})+\mathrm{CO}(\mathrm{g})
$$

Thus, Nicalon must crystallize completely into $\beta$-SiC

$$
\mathrm{SiC}_{1.21} \mathrm{O}_{0.40} \rightarrow \mathrm{SiC}(\mathrm{s})+\mathrm{SiO}(\mathrm{g})+\mathrm{CO}(\mathrm{g})
$$

The chemical analysis of Nicalon exhibited that the $\mathrm{C} / \mathrm{SiC}$ molar ratio approached asymptotically unity with the progress of pyrolysis. ${ }^{6)-8)} \beta$ - $\mathrm{SiC}$ crystals grow while $\mathrm{SiC}_{x} \mathrm{O}_{y}$ phase decomposes. For Hi-Nicalon, which contains a slight amount of $\mathrm{SiC}_{x} \mathrm{O}_{y}$ phase, the crystal growth is completed at an early stage of heat treatment. In addition, free carbon, which exists around $\beta$-SiC crystals, appears to disturb further coarsening of the crystals, as can be seen from Fig. 5. Hi-Nicalon kept its fibrous form and was flexible even after heating at $2273 \mathrm{~K} .{ }^{1)}$ On the other hand, the grain structure of Nicalon was coarsened markedly by subsequent heating after the completion of pyrolysis, owing to the disappearance of free carbon. ${ }^{6)}$ Furthermore, in addition to the pyrolytic reaction, the gas-phase reaction also occurred among pyrolytic gases $\mathrm{SiO}, \mathrm{CO}$ and free carbon, producing huge $\beta$ $\mathrm{SiC}$ crystals at fiber surface (Figs. 7 and 8 ).

$$
\begin{aligned}
& \mathrm{SiO}(\mathrm{g})+2 \mathrm{C}(\mathrm{s})=\mathrm{SiC}(\mathrm{s})+\mathrm{CO}(\mathrm{g}) \\
& \mathrm{SiO}(\mathrm{g})+3 \mathrm{CO}(\mathrm{g})=\mathrm{SiC}(\mathrm{g})+2 \mathrm{CO}_{2}(\mathrm{~g})
\end{aligned}
$$

In order to grow $\beta$-SiC crystals further, the fibers must fully liberate $\mathrm{SiO}$ and $\mathrm{CO}$ gases. The gases can escape more readily from the surface than from the core of fiber. Therefore, the grown and coarsened crystals were distinctly observed at the fiber surface after a brief period of heating (Fig. 8). In addition, many micro-pores were formed at the surface of Nicalon which evolved vigorously large quantities of gas. Such a pyrolysis will result in severe degradation of $\mathrm{SiC}$ fiber. In the first place, the damaging effect of crystal coarsening on fiber strength must be considered. The tensile strength, $\sigma$, was correlated fairly closely with the crystal size of $\beta$-SiC, $D_{111}$, in SiC fibers by the empirical expression ${ }^{4), 5)}$

$$
\sigma=a+b \cdot D_{111}^{-1 / 2}
$$

where $a$ and $b$ are constant. Equation (7) is similar to the relation which holds in a polycrystalline ceramic with small grains. ${ }^{12)}$ This correlation can be seen from Fig. 9, where the tensile strength is plotted against the reciprocal of the square root of crystal size. The gradual degradation of fiber strength over long heating time is apparently caused by the crystal growth (Figs. 2 and 5). At the same crystal size, the tensile strength of Nicalon is much lower than that of HiNicalon. The reason is apparently because severe degradation of Nicalon occurs rapidly at early stage. A vigorous evolution of $\mathrm{SiO}$ and $\mathrm{CO}$ produces micro-pores as the primary cause of the degradation (Figs. 7 and 8).

The amount of gases evolved was evaluated by using the mass loss determined by TG. Figure 10 shows the relationship between tensile strength and mass loss for $\mathrm{Hi}$ Nicalon and Nicalon. A very large decrease in strength is occurred within the first 2 to $3 \%$ mass loss. The formation of strength-controlling pores, as a consequence of the rapid evolution of $\mathrm{SiO}$ and $\mathrm{CO}$ gases (Fig. 1), may lead to the ini-

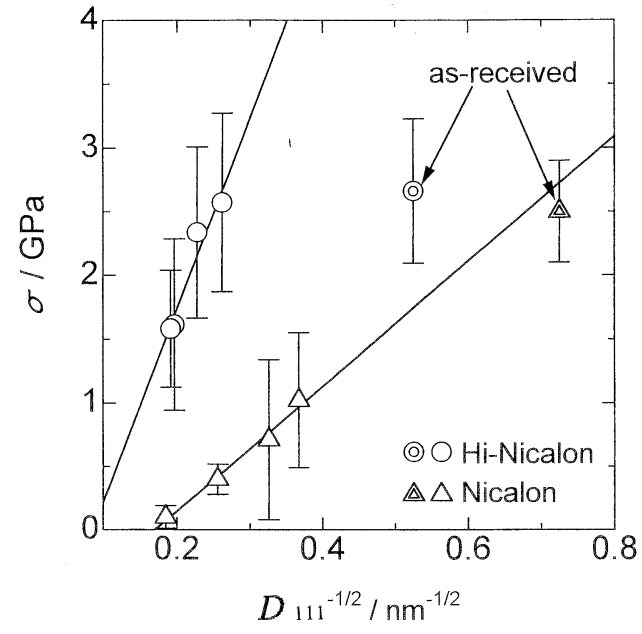

Fig. 9. Relationship between tensile strength and crystal size of $\beta$-SiC in fibers heated at $1873 \mathrm{~K}$.

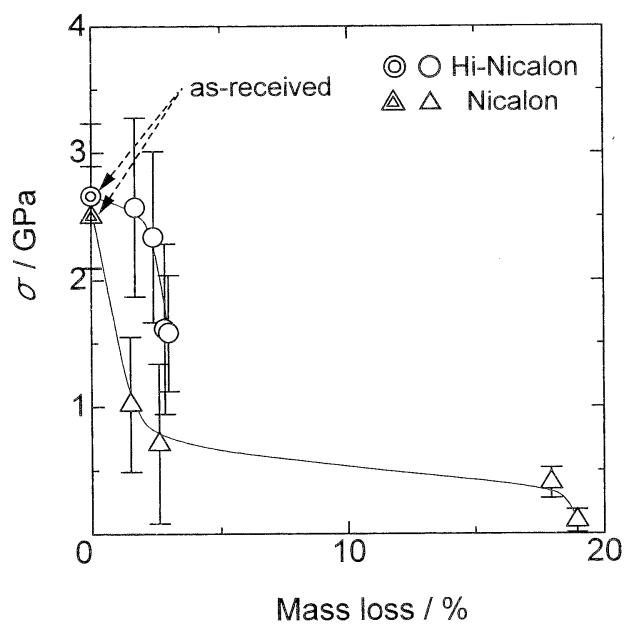

Fig. 10. Relationship between tensile strength and mass loss for fibers heated at $1873 \mathrm{~K}$.

tial severe degradation of strength. At the same amount of gas evolved, the strength of Nicalon is lower than that of Hi-Nicalon. As can be seen from SEM observation (Figs. 7 and 8 ), this is because Nicalon is more porous than Hi-Nicalon. The generation of $\mathrm{SiO}$ and $\mathrm{CO}$ results in the increase in porosity of fibers. Further heating Nicalon, therefore, led to a very coarse structure with significantly increased porosity. Finally, tensile strength became too low to measure, while Hi-Nicalon was retained considerable level of strength.

The reduction in fiber strength is caused by the combination of crystal growth and the generation of $\mathrm{SiO}$ and $\mathrm{CO}$ gases. The schematic models for the degradation of polymer-derived $\mathrm{SiC}$ fibers are shown in Fig. 11. The presence of free carbon in Hi-Nicalon and the formation of deleterious micro-pores in Nicalon play notably an important role in the degradation.

\section{Conclusion}

SiC fibers fabricated by firing at $1273 \mathrm{~K}$, Hi-Nicalon (1.8 mass $\% O$ ) and Nicalon (13 mass \%O), were heated at 1873 $\mathrm{K}$ and the pyrolytic mechanism were investigated. The following results were obtained:

(1) A brief period of heat treatment changed rapidly the properties of fibers: generation of $\mathrm{SiO}$ and $\mathrm{CO}$, tensile 


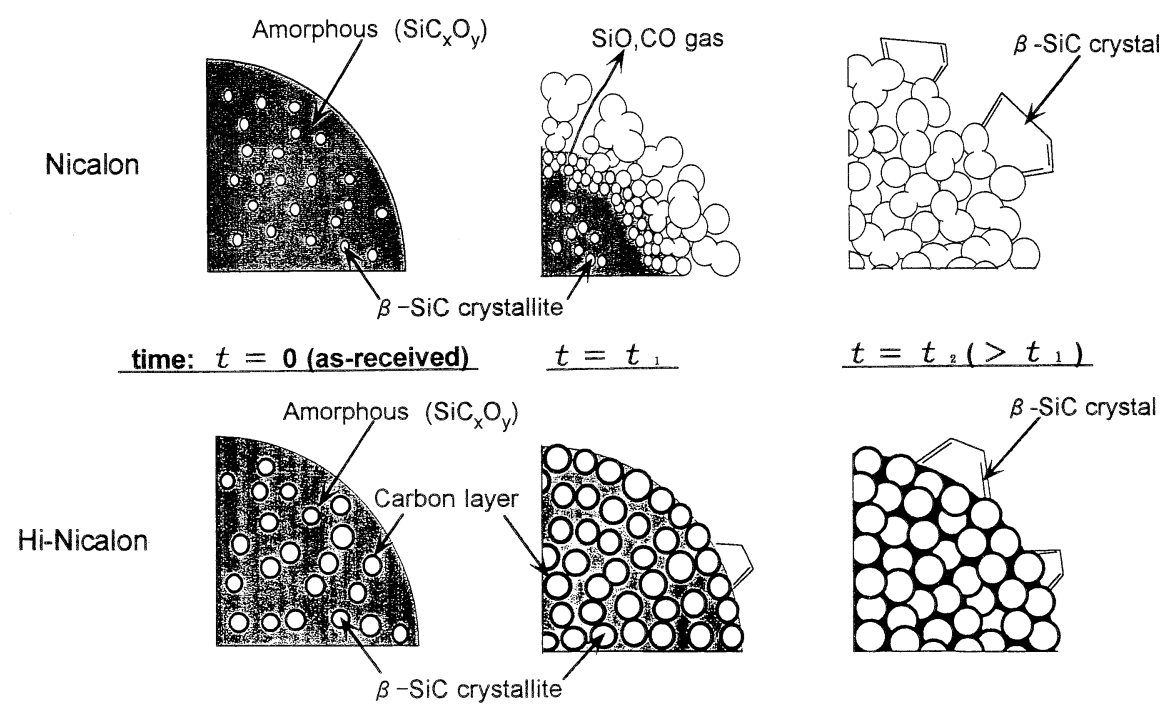

Fig. 11. Schematic model for degradation Nicalon and Hi-Nicalon at high temperature.

strength, $\mathrm{SiC}$ crystal size and specific resistivity.

(2) Nicalon was porous after pyrolysis, because of violent gas generation. $\beta$-SiC crystals grew inwardly from the surface to the core of fiber. Hi-Nicalon, however, was free of micro-pore, though the crystal size was large.

(3) The fiber strength was proportional to the reciprocal square root of $\mathrm{SiC}$ crystal size. At the same crystal sizes, Nicalon showed lower strength because of the formation of micro-pores.

(4) The crystal size and porosity were found to be the important factors in controlling fiber strength. Hi-Nicalon showed high level of strength because of slow crystal growth and slightly liberated gases.

Acknowledgement This study was supported in part by the Ministry of Education, Science, Sports and Culture under Grant No. 07650800. The authors would like to thank Mr. Michio Takeda and Dr. Hiroshi Ichikawa (Nippon Carbon Co., Ltd.) for supplying SiC fibers and for helpful discussions.

\section{References}

1) M. Takeda, Y. Imai, H. Ichikawa, T. Seguchi and K. Okamura, Ceram. Eng. Sci. Proc., 12, 1007-12 (1991).

2) M. Takeda, Y. Imai, H. Ichikawa, T. Seguchi and K.
Okamura, Ceram. Eng. Sci. Proc., 13, 209-17 (1992).

3) T. Shimoo, T. Hayatsu, M. Narisawa, M. Takeda, H. Ichikawa, T. Seguchi and K. Okamura, J. Ceram. Soc. Japan, 101, 1379-83 (1993).

4) T. Shimoo, T. Hayatsu, M. Takeda, H. Ichikawa, T. Seguchi and K. Okamura, J. Ceram. Soc. Japan, 102, 1142-47 (1994).

5) T. Shimoo, T. Hayatsu and K. Okamura, J. Jpn. Soc. Powder and Powder Metallurgy, 43, 118-21 (1996).

6) T. Shimoo, M. Sugimoto and K. Okamura, Nippon Kinzokugakkai-shi, 54, 802-08 (1990).

7) T. Shimoo, H. Chen and K. Okamura, J. Ceram. Soc. Japan, 100, 48-53 (1992).

8) T. Shimoo, M. Sugimoto and K. Okamura, Seramikkusu Ronbunshi, 98, 1324-29 (1990).

9) E. Bouillon, F. Langlais, R. Pailler, R. Naslain, F. Cruege, P. V. Huong, J. C. Sarthou, A. Delpuech, C. Laffon, P. Lagarde, M. Monthioux and A. Oberlin, J. Mater. Sci., 26, 1333-45 (1991).

10) M. Monthioux, A. Oberlin and E. Bouillon, Comps. Sci. Technol. 37, 21-35 (1990).

11) C. Laffon, A. M. Flank, P. Lagarde, M. Laridjani, R. Hagege, P. Olry, J. Cotteret, J. Dixmier, J. L. Miquel, H. Hommel and A. P. Lagrand, J. Mater. Sci., 24, 1503-12 (1989).

12) W. D. Kingery, H. K. Bowen and D. R. Uhlmann, "Introduction to Ceramics," John Wiley \& Sons, Inc., New York (1976) pp. 791-97. 